\section{Alternative food distribution networks, resilience, and urban food security in Turkey during the COVID-19 pandemic}

\author{
Nurcan Atalan-Helicke a* \\ Skidmore College \\ Bürge Abiral ${ }^{b}$ \\ John Hopkins University
}

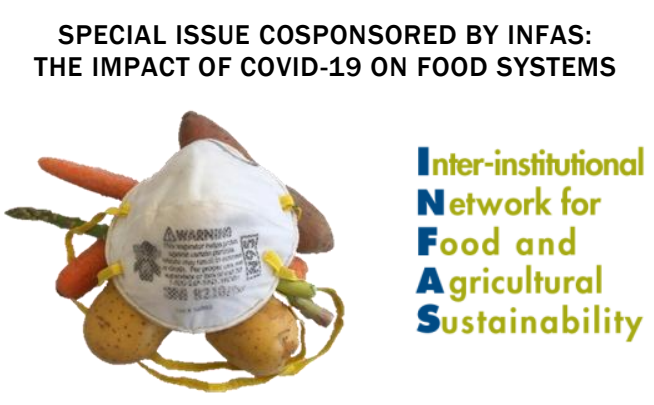

Submitted September 15, 2020 / Revised November 12, December 7, and December 8, 2020 /

Accepted December 8, 2020 / Published online March 16, 2021

Citation: Atalan-Helicke, N., \& Abiral, B. (2021). Alternative food distribution networks, resilience, and urban food security in Turkey during the COVID-19 pandemic. Journal of Agriculture, Food

Systems, and Community Development, 10(2), 89-104. https://doi.org/10.5304/jafscd.2021.102.021

Copyright (C) 2021 by the Authors. Published by the Lyson Center for Civic Agriculture and Food Systems. Open access under CC-BY license.

\begin{abstract}
This article explores the potential of alternative food networks (AFNs) for food security and resilience as COVID-19 has raised challenges to the global food supply chain. Pandemic-induced disruptions to conventional food production, distribution, and consumption networks have revealed problems with the global food system and have drawn attention to the re-localization and regionalization of food systems. Lockdown and mobility restrictions have also disrupted the availability, quality, and stability of food. We evaluate how
\end{abstract}

a * Corresponding author: Nurcan Atalan-Helicke, Ph.D., Associate Professor, Skidmore College; 815 North Broadway; Saratoga Springs, NY 12866 USA; +1-518-580-8372; natalanh@skidmore.edu

b Bürge Abiral, Ph.D. Candidate, Zanvyl Krieger School of Arts \& Sciences, Department of Anthropology, John Hopkins University; 466 Mergenthaler Hall, 3400 N. Charles Street; Baltimore, MD 21218 USA; babiral1@jhu.edu

\section{Funding Disclosure}

Bürge Abiral's research is supported by the National Science Foundation Cultural Anthropology Program under grant number 1823710.
AFNs have responded to these challenges in a non-western context through a case-study approach informed by participant observation and semistructured interviews. After examining the multiple factors that have been critical to the emergence and expansion of AFNs in Turkey since the mid-2000s, we argue that these food distribution networks have aimed to address food security, environmental sustainability, and farmer livelihoods in complementary ways. We provide a timeline of state-led measures in response to COVID19 in Turkey as we consider their impacts on food distribution systems and access in urban areas. We then compare two AFNs: a food community working within a participatory guarantee system, and a

\section{Authors' Disclosure}

Both authors are members of the online group Natural Food Network; the first author has been a member since 2014, and the second author since 2019. The second author has worked as a volunteer at Kadıköy Cooperative since January 2019. She is also an official partner of Kadıköy Cooperative. As per the cooperative's structure, she receives no financial benefit from the partnership. Neither author receives any financial or other benefit by publishing this article. 
consumer cooperative that connects producers and consumers in urban areas. Although the two AFNs faced initial challenges due to disruptions in delivery services and lockdowns, they have been able to continue their services and address increasing demand. They also provided special solidarity packages for those adversely affected by the economic impacts of COVID-19. By building on the existing networks and relationships of trust between consumers and producers, and the capacity and willingness of producers to adapt to the new regulatory environment, the two AFNs have been able to continue their activities and start new initiatives.

\section{Keywords}

Alternative Food Networks, COVID-19, Turkey, Pandemic, Food Security, Resilience

\section{Introduction}

The COVID-19 pandemic has disrupted global food supply chains and exposed systemic weaknesses (Zurayk, 2020). Whereas some places have suffered from empty grocery shelves, others have experienced food loss due to fresh produce accumulating at farms (Held, 2020; Torero Cullen, 2020). As more people live in urban areas and depend on markets and distribution networks, social distancing measures have limited the internal and external logistics of food distribution networks. The short-term impacts of COVID-19 may also differ across the global North and South (Chin, 2020; Crush \& Si, 2020; Skerritt, Patton, \& Onu, 2020). Outbreaks of the disease and a lack of personal protective equipment have undermined the operation of food processing plants, food harvests, and market operations. At the same time, consumers have faced purchasing limits, higher prices, or fewer choices (Elejalde-Ruiz, 2020; Gallagher \& Kirkland, 2020).

Although the long-term impacts of the COVID-19 outbreak remain unclear, the pandemic has raised new questions about food security and resilience. Here, we define food system resilience as the capacity and ability to withstand and overcome disturbances (Worstell \& Green, 2017). As the scope of the crisis continues to be assessed, several authors have called for food systems to strengthen their resilience by becoming more localized (Clapp, 2020; Held, 2020; Temürcü, 2020). The spread of COVID-19 has adversely and unevenly affected producers, transporters, processors, retailers, vendors, and consumers in local and national food systems by affecting the availability of food, access to it and its stability (Béné, 2020). Implicit in calls for more resilient local food systems has been the understanding that the global food system has remained as fragile as ever.

Recent academic literature on alternative food networks (AFNs) has given attention to these calls for the localization of food systems. Localization often refers to shortening the supply chain by eliminating, for instance, intermediary distributors, and increasing the geographic proximity between producers and consumers. Such place-based alternatives offer self-sufficiency while ensuring traceability. AFNs also promote alternatives to global industrial food production, including fair treatment of workers and sustainable agricultural production (Chase \& Grubinger, 2014). As in the case of food hubs or cooperatives, AFNs expand local food distribution networks and help small farmers access larger markets and preserve their livelihoods (Perrett \& Jackson, 2015).

Despite well-established research on AFNs and their contributions to food security and resilience, ${ }^{1}$ the existing literature gives inadequate attention to the role of AFNs in the global South and their contributions to food systems (Pratley \& Dodson, 2014). Likewise, during the pandemic, we have heard more about COVID-19 responses from the global North. ${ }^{2}$ This paper aims to close this gap in the literature. By considering a case study from Turkey, we discuss how two AFNs that have been connecting producers and consumers effectively in urban areas of the country have responded to the COVID-19 pandemic, which challenges these net-

\footnotetext{
1 See the Ackerman-Leist (2013) and Jarosz (2008) for a case study of the U.S.; Levkoe (2014); Sumner, Mair \& Nelson (2010) for Canada; Larder, Lyons \& Woolcock (2014) for Australia and Blake, Mellor \& Crane (2010) for U.K.

${ }^{2}$ Food studies journals published in English, including the Agriculture Human Values, Gastronomica, Food and Foodways, and this journal have published articles and reflections on the impact of COVID-19 and food systems starting in the summer and fall of 2020.
} 
works have faced in the short term, and what kinds of promises they hold for the localization of food systems. We focus on two AFNs: the online Natural Food, Conscious Nutrition Network food hub (Doğal Besin, Bilinçli Beslenme Ağ1, referred to as Natural Food Network hereafter) and a consumer cooperative, Kadıköy Cooperative. These AFNs operate in two urban centers respectively: Ankara, Turkey's capital, and Istanbul, the country's financial center, where $18 \%$ of its population resides. Istanbul also constitutes about one-third of the food transportation flows in Turkey (Aslan \& Demir, 2018). We argue that these AFNs were able to continue their distribution under serious lockdown and mobility restrictions during the initial months of COVID-19 due to the diversity of producers within their networks, their flexibility in procurement and distribution, and the ability of their producers to use household labor. They were also able to adapt quickly and respond to disruption in a way that did not undermine the well-being of the producers or consumers in their networks. However, due to lockdown measures affecting those over the age of 65 and those with chronic health conditions, not all producers were able to connect to consumers immediately. ${ }^{3}$

In the new regulatory environment that has emerged after COVID-19, these two AFNs have been quick to address challenges on the consumption side with calls for solidarity, adjusted work hours, and practices conforming to new mandates for social distancing. They have also continued to serve urban consumer centers with fresh, healthy, and good food. ${ }^{4}$ On the producer side, they have coordinated the smooth movement of fresh and processed food items so that their food would not be wasted and nutritious food would be available for consumers. Their adaptations to the new and changing regulations have been swift. Although delays in mail deliveries for the Natural Food
Network and reductions in Kadıköy Cooperative's hours of operation decreased both organizations' interactions with consumers, both have been able to continue food distribution and maintain relatively normal operations. As the two cases demonstrate, stronger local and regional food systems have ensured both economic opportunity for small producers and access to fresh and clean food for consumers in densely populated urban centers during and after disturbances. Both AFNs have also adapted to offer solidarity purchases where producers and consumers purchase items for people in need in Ankara and Istanbul, suggesting that the AFNs have the capacity to move quickly to respond to food security aftershocks.

After a review of relevant scholarship, we discuss the emergence and roles of AFNs in Turkey. Then we chronicle the regulatory measures taken in Turkey in response to COVID-19. After outlining our methodology, we move to the case studies. We examine in detail the organizational background of the Natural Food Network and Kadıköy Cooperative and focus on their responses to COVID-19. These case studies scrutinize how each organization reacted with new approaches to the changing regulatory environment and to the new challenge of food insecurity raised due to the pandemic. We end with a discussion comparing the responses of these two AFNs and evaluate their ability to respond to disturbance, while also acknowledging their limitations.

\section{Background}

\section{Alternative Food Networks}

AFNs emerged as a response to the environmental externalities of the industrialized and globalized food system and to pervasive social and economic inequalities (Alkon \& Guthman, 2017; Chase \& Grubinger, 2014; Holt Giménez \& Shattuck, 2011).

\footnotetext{
3 According to the Turkish Chamber of Agricultural Engineers, most of the producers in conventional agriculture as well as AFNs in Turkey are over the age of 55 (Değirmenci, 2020).

4 AFNs in Turkey use different descriptors to define the food they circulate: While not all of the food distributed through AFNs is certified as organic, they emphasize descriptors as fresh, clean, healthy, good, just food to define production following agroecological principles that also respect and preserve local seeds and farm labor justice. A lack of trust in private certification agencies and the difficulties faced by smallholders in accessing certification make organic certification unnecessary, if not undesirable, for many (see Soysal Al \& Küçük, 2019). For that reason, these networks rely on different forms of trust-building, such as the establishment of participatory guarantee systems (PGS).
} 
As such, they represent "efforts to respatialize and resocialize food production, distribution and consumption" (Jarosz, 2008, p. 231). AFNs not only procure and distribute food through alternative channels, such as farmers markets, consumer cooperatives, and premium specialty food and voluntary labels (fair trade, organic, etc.), they also offer a range of food-related activities (Ackerman-Leist, 2013). ${ }^{5}$ By eliminating intermediaries from the process, direct marketing efforts by AFNs bring producers and consumers together and help them develop bonds of trust. These trust relationships bypass third-party certification systems and allow participatory guarantee systems (PGSs) ${ }^{6}$ to ensure the quality of food (Loconto \& Hatanaka, 2018). Producers within AFNs often prohibit or strive to limit the use of certain conventional inputs and practices, think about the ecological footprint of food production from seed to waste, and incorporate diverse practices and crops (Chase \& Grubinger, 2014).

Different values shape the work of AFNs. At their heart is a desire for decentralization, independence from fossil fuels and other inputs, community at local and regional levels, harmony with nature, diversity in practices and crops, and restraint from abusing nature, workers, and animals (Sumner et al., 2010). Several AFNs, particularly those in the global South, consciously resist corporatization (Fraser, 2017; Holt Giménez \& Shattuck, 2011). Thus, some producers within AFNs reject genetically modified (GM) agriculture and seeds, citing implications for patenting life, ecosystem impacts, and ethical concerns. AFNs have increased the availability and variety of locally grown foods in several communities (Nelson \& Stroink, 2014). Cooperative food systems, a subset of AFNs, create a web of mutually beneficial activities for producers and consumers. Based on their commitment to cooperation and democratic processes, they also aim to reshape the dominant social-economic organization of food systems (Sumner, McMurtry, \& Renglich, 2014). AFNs face tension in balancing the affordability of local, organic, or healthy food with viable incomes for producers, but their emphasis on local food systems creates complex adaptive systems (Nelson \& Stroink, 2014).

Scholarly literature has also considered problems associated with alternative foodscapes. ${ }^{7}$ Although AFNs have defied simplistic categorization, many have responded to injustices and problems of the corporate food regime through various methods and practices, within and across countries (Fraser, 2017). As they incorporate strategies from anti-hunger and food sovereignty initiatives, support small farms and local production, and advocate for sustainable agriculture, clean food, and health, AFNs have occupied an oppositional status and enjoyed transformative potential to deliver progressive systemic change in food provisioning (Goodman \& Goodman, 2009).

\section{AFNs in the Turkish Context}

An upper-middle-income economy, Turkey has achieved significant economic and social develop-

\footnotetext{
5 Other activities AFNs engage in include, but are not limited to, educating about and growing food; developing formal policy and infrastructure; implementing initiatives reconnecting producers and consumers such as field days; conserving agricultural land; and developing mechanisms to enable the participation of all consumers (Ackerman-Leist, 2013).

${ }_{6}$ Participatory guarantee systems (PGS) are networks that consist of farmers, experts, public sector officials, food service agents, and consumers. They reallocate authority away from experts to a multistakeholder group. They help certify producers based on active participation of stakeholders and are built on a foundation of trust, social networks, and knowledge exchange. Connecting consumers to producers, the PGSs "create a local system of production and consumption whereby multiple stakeholders experiment with sustainable agriculture technologies on farms, but also collectively ensure that the organic agriculture techniques are adopted by setting standards and verifying their compliance” (Loconto \& Hatanaka, 2018, p. 415).

${ }_{7}$ AFNs were criticized for allowing the privileged class to continue consumption by emphasizing the sale of alternatives (Allen, 2008). AFNs were also criticized for failing to address structural problems in the system, such as the state's responsibility in regulating environment and health (Alkon \& Guthman, 2017). As organic and fair trade labels become more popular, these production methods can also be co-opted by multinational corporations and supermarket chains (Fraser, 2017; Guthman, 2004). Some labels may not always live up to the standards they put forth (Besky 2014). In the U.S., the sustainable agriculture movement has also been criticized for privileging the economic needs of small and organic producers rather than addressing the needs of low-income people (Guthman, Morris, \& Allen, 2006).
} 
ment results since the early 2000s (World Bank, 2017). The number of people living and employed in rural areas of Turkey has been declining since 2000, both in absolute and relative terms (Kan et al., 2019). As a result of legislative changes in 2013 (Law No. 6360), which redefined rural areas and classified villages as neighborhoods of municipalities, exact figures for the rural population are unknown (Republic of Turkey Ministry of Development, 2019). ${ }^{8}$ Agricultural policies since the 2000s have expanded neoliberal policies into the agricultural sector, and state support for farming largely has been withdrawn (Aydin, 2010). Although Turkey recovered quickly from the 2009 global financial crisis and enjoyed high growth rates until 2015, this recovery also resulted in large external and internal imbalances (World Bank, 2017). Following a failed coup attempt in 2016 and geopolitical turmoil, Turkey's gross domestic product (GDP) was projected to decline by $3.8 \%$ in 2020 (World Bank, 2020). When the pandemic started, the burden of Turkey's external debt was already affecting its economy. The most prolonged recession of 2018 has been characterized by persistently low or negative rates of growth, dwindling investment performance, problems repaying debt, rising unemployment, a spiraling currency depreciation, and high inflation (Orhangazi \& Yeldan, 2020). As prices in imported goods and inputs for agricultural prices have increased, food prices have also spiked, and the depreciation of the Turkish lira has reduced the purchasing power of consumers.

Legal changes, including the Wholesale-Market Law (Law No. 5957) and Seed Law (Law No. 5553), encouraged the consolidation of food distribution networks and supermarket chains and have made it difficult for small producers to compete against larger producers (Atasoy, 2017). A range of food scares, including mad cow disease and bird flu, incurred significant economic and social costs and provoked consumer anxieties. The lengthening of food supply chains, increasing food imports, presence of synthetic ingredients in food, and scandals involving tainted food have also brought shifting nutritional advice to consumers, who have lost their trust in the state and markets (Atalan Helicke, 2020). While manufacturers and retailers have worked to re-establish consumer trust, grassroots movements by activists, consumers, and nongovernmental organizations (NGOs) in Turkey have also pursued initiatives to address these anxieties and establish closer links to producers.

(Nizam \& Yenal, 2020)

Similar to factors in the emergence of AFNs in the North, AFNs in Turkey focus on localization. In the Turkish context, "local" means working with other local organizations, groups, and initiatives on the basis of trust relationships, and following principles of ethics and justice in food access (Doğançayır \& Kocagöz, 2018). Efforts in Turkey to shorten the food supply chain and promote localization include serving a specific geographic area (Kadıköy Cooperative), working with consumers in a particular place (Natural Food Network), and collaborating with producers in a certain place. Several AFNs in Turkey emphasize "good-cleanjust agriculture" principles (Çelik, 2016). They have also built stronger connections between small producers and consumers through organic farmers markets and weekly bazaars (pazar $)^{9}$ in urban centers of Istanbul and Ankara, and they have tapped into online forums to create collective initiatives. A common concern is urban consumers' access to food produced by sustainable practices or respect for labor justice.

The number of AFNs in Turkey that provide community supported agriculture (CSA) or partici-

\footnotetext{
8 Coinciding with the aftermath of the 2009 global financial crisis, the agricultural policy changes resulted in "a mass urban flow (urban-directed migration), and the formation of extended (rural-urban) settlement structures involving various types of mobility and novel living structures" (Öztürk, Topaloğlu, Hilton, \& Jongerden, 2018, p. 516) A new phenomenon called "retirement villages" is changing village characteristics: People return to their hometowns or parents' villages to farm both as an "income-generating" activity and "as a strategy to resist commodification in agriculture" (Öztürk et al., 2018, p. 513).

9 A pazar is an outdoor market serving different neighborhoods one day a week year around. These markets are managed by the municipalities. Middlemen often sell fresh fruits, vegetables, cheese, eggs, honey, legumes, and other dried food, along with small kitchen and bathroom items, such as pans, salt shakers, and mirrors. They often sell conventionally grown items without a label of the origin for fresh fruits and vegetables.
} 
patory guarantee systems (PGS) has increased from 10 in 2015 (Urgenci, 2016) to 43 in 2020 (Gida Topluluklar1, 2020). We date the emergence of these AFNs to the early 2000s and to two interlinked phenomena. First, the Buğday Association for Ecological Living (referred to as Buğday from now on), an Istanbul-based NGO, has been a leading actor in the clean and healthy food movement since its founding in 2002. Buğday has established organic farmers markets and a seed conservation and exchange network, initiated agricultural tourism (a project bringing volunteers to ecological farms), and implemented several other projects connecting consumers and producers. Similarly, its campaigns, such as its effort to ban toxic chemicals from agricultural production, have created public awareness about clean food. Altogether, these efforts have also contributed to the formation of a network of individuals who have become leaders in establishing food communities or working toward policy change (Buğday, n.d; Çanga, Kutlu, \& Çalışkan, 2018). Second, Buğday and other actors established a network in 2004 to reduce the use and import of GM food in 2004, thereby enhancing solidarity and collective action among grassroots organizations. ${ }^{10}$ Since then, the organizations within these networks have worked closely to build sustainable food systems. Led by an umbrella organization of environmental and consumer rights groups, academicians, groups representing agricultural engineers, producer associations (e.g., the Confederation of Farmer Unions), doctors associations, and organic certification agencies, the antiGM platform made grassroots demands for clean and healthy food more visible in the public arena.

Before COVID-19, each AFN we examine had a well-established network and connected small producers engaged in sustainable food production practices with mainly middle-income urban consumers in major urban centers in Turkey. They had access to the crops grown by a diversity of producers, who maintained successful traditional varieties, such as heirloom varieties and landraces. Yet, these producers were flexible enough to incorporate innovation. These two AFNs generated sufficient income to maintain their operations and support small producers. The producers they worked with farmed in different places in Turkey and relied mainly on family and friends for labor. Small producers may have high vulnerability to shocks due to their small or micro-scale operations, lack of access to insurance, and insufficient cash flow. Over the years, however, these AFNs devised methods to support small producers. They developed trust relationships among consumers and producers and remained active during political and economic crises in Turkey. In this sense, they effectively addressed disturbances and worked toward building a resilient food system while ensuring livelihoods for small producers.

Both the Natural Food Network and Kadiköy Cooperative emphasize collective food systems and reject hierarchy. The initiatives are organized differently. The Natural Food Network is a decentralized network. It emphasizes CSAs and PGS, coordinates exchanges between consumers (threefourths of whom are in Ankara) and producers around Turkey. Kadıköy Cooperative provides a physical space where fresh crops and processed food items are gathered from small producers throughout Turkey and sold to consumers in the Kadiköy neighborhood of Istanbul, with an emphasis on solidarity economy and grassroots mobilization.

\section{COVID-19 and Response: Regulatory Measures and Impacts on $A F N s$}

Turkey reported its first COVID-19 case on March 11,2020, and like many other countries, started to implement stay-at-home measures starting March 15. All K-12 education was closed for a week, then resumed remotely. All non-essential businesses were closed gradually between March 15 and March 21, while community prayers at mosques were banned. Age-based curfews for those over 65 years old and younger than 20 years old were implemented. Restaurants and pastry shops were kept open for to-go orders. Limited grocery store and supermarket hours ( 9 a.m. to 9 p.m.) were announced on March 24 throughout Turkey

10 Turkey does not cultivate GM crops. It has imported GM animal feed since 2011, and continues food imports from countries that cultivate and process GM crops (Atalan Helicke, 2015). 
(Karadağ, 2020). Farmers markets and pazar continued to operate under new guidelines, such as increased distance between stands, restrictions on the number of visitors, and the prepackaging of all food items. Grocery stores and supermarkets were allowed to admit only a limited number of customers at a time, corresponding to one tenth of their usual capacity (Karadağ, 2020). Lines of consumers in front of markets became common in densely populated areas of metropolitan cities, while some people resorted increasingly to online markets or market delivery systems. Restrictions on intercity travel did not extend to food and agricultural items. Even when there were delays, stocks were quickly replenished. Yet, the prices of a variety of food items increased dramatically (Yildırım, 2020).

After the first few weeks, universal curfews were imposed in metropolitan cities, first over the weekends, then over extended holidays (April 2326 and May 16-19). ${ }^{11}$ During weekend curfews, only bakeries selling bread and other food items and drinking water vendors were allowed to operate, provided they worked with a delivery system (CNNTürk.com, 2020). People were still not allowed to go outside their homes, except to shop in neighborhood grocery stores and bakeries or to receive home deliveries between specific hours $(9$ a.m.-2 p.m. during April 23-26, and 10 a.m.4 p.m. during May 16-19).

COVID-19 measures affected the agricultural sector in Turkey in many ways, as the pandemic coincided with both the planting and harvest seasons for different crops. In the fields, workers risked exposure to the virus and had to practice social distancing and wear masks. Although exceptions were granted by local authorities (Özdemir, 2020), many farmers were restricted from working outside due to the age-based curfews or safety measures. New guidelines for transportation and for accommodation of seasonal farm workers were announced, but these largely failed to provide a safe working environment (Zirh et al., 2020). Since the agriculture sector was excluded from the government's Economic Stability Shield program to provide financial relief during the crisis, producers did not receive any financial support during this period.

\section{Problem Statement}

Examining these two organizations in Turkey helps us understand how AFNs emphasizing collective food systems address short-term challenges during significant disruptions. These AFNs have shifted their operations and priorities in line with a shift in the regulatory environment and adapted different mechanisms to ensure that consumers and producers maintain trust. Although Turkey has been prone to lockdowns historically due to periodic political crises or authoritarian policies,${ }^{12}$ the period examined here represented the longest series of lockdowns for the majority of the population with consequences for food production (e.g., planting and harvest) and consumer access. A few of these lockdowns coinciding with religious holidays have led to a consumer rush to markets and increases in food prices (Abiral \& Atalan-Helicke, 2020). However, general food availability has not fluctuated in Turkey. Reduced wages and loss of income have destabilized food security for some in large urban centers. In response, the solidarity mechanisms these AFNs fostered between consumers and producers provide a model of how to maintain both small producer livelihoods and urban food security.

\section{Methods}

Case study research design, participant observation, and semistructured interviews allow us to understand the experiences, processes and practices of

\footnotetext{
11 By June 1, 2020, Turkey reported a total of 166,000 COVID-19 positive cases and 4,609 deaths. The highest daily reported cases were about 2,000 in March; 5,000 in April; and 1,600 in May. Turkey eased most of the lockdowns by midsummer. It is compulsory to wear masks in Turkey (fines are charged to those who do not wear masks at 900 Turkish liras, equivalent to US\$130). As of November 12, 2020, Turkey reported a total of 404,000 cases and 11,200 deaths.

12 For a generation over a certain age and for certain regions in Turkey, lockdowns are not uncommon, but for younger generations (particularly those in Ankara and Istanbul), lockdowns are a new phenomenon. Heper and Evin (1988) examine the protests, lockdowns, and political instability in Turkey after the 1970s, and the impact of the 1980 coup d'état on democracy and civilian-state relations. Mecellem (2018) discusses the continuing political crisis in Turkey's southeast starting in the 1990s and the impact of lockdowns on the human rights of Kurdish minorities.
} 
AFNs (Jarosz, 2008). Case study methodology focuses on an intensive analysis of an individual unit (as a person or community) to understand the particularity and complexity of a phenomenon (Harrison, Birks, Franklin, \& Mills, 2017). In the internet age, digital communication through email listservs as well as social media shares also has become part of the natural setting used in the analysis of case study research (DeWalt \& DeWalt, 2011).

In this article, our analysis focuses on how these two AFNs responded to COVID-19 between March and May 2020. We examined email exchanges between producers and consumers in the online discussion group of Natural Food Network, and social media announcements of Kadıköy Cooperative between March 13, 2020, and May 25, 2020. In addition, we reviewed articles, reports, and popular news stories in English and Turkish about AFNs (after 2005) and COVID-19. We filtered these sources through keywords, such as food community, food group, food security, small farmer, COVID-19, coronavirus, and social-distancing measure. While the first author interviewed two producers in the Natural Food Network in July 2019 and two moderators in May 2020, the second author has been conducting ethnographic fieldwork with various actors involved in AFNs in western Turkey.

\section{Case Studies}

\section{Natural Food Network (Doğal Besin, Bilinçli Beslenme A $\breve{g r}$ )}

\section{Organizational background}

The Natural Food Network was established in 2009 to connect consumers in Ankara with producers who produce according to agro-ecological principles. The producers connect with consumers via an email listserv, WhatsApp, and a phone order system. After receiving orders, many producers ship their produce or processed food items via courier service or postal shipments. Producers closer to Ankara deliver their products directly to drop-off points using their own vehicles.

There are 25 producers in Natural Food Network; 20 have been members for more than three years. Producers are located at different distances from Ankara, a city in central Anatolia with a semiarid continental climate. The closest producers are located in the villages of Güneşköy $(50 \mathrm{~km}$ or 31 miles from Ankara), where there is an eco-village, and Tahtaörencik $(104 \mathrm{~km}$ or 65 miles from the capital), which hosts a producer cooperative. These villages provide CSAs for vegetables, eggs, meat, cosmetic products, and herbal supplements.

The Natural Food Network provides over 100 different food and food products. While its initial mission was to expand "local production and local consumption," the limited availability of fresh fruits and vegetables due to the seasonality of production in Ankara requires the procurement chain to include all of Turkey (personal communication, ${ }^{13}$ May 18, 2020). The service area of the Natural Food Network is "local": as of May 2020, $77 \%$ of its consumers are from Ankara, followed by $13 \%$ who are from Istanbul. These two urban centers constitute $90 \%$ of all its consumers. ${ }^{14}$ Periodic consumer surveys since 2016 show that the Natural Food Network has an average of 203 new members per year. ${ }^{15}$

The mission of Natural Food Network is multifold; it endeavors to establish trust among consumers and producers through direct marketing, support small producers, expand agro-ecological production, enable consumers' access to clean and healthy food, support CSAs and other food communities, engage in collective action to address the food system problems, and facilitate PGS that works on a volunteer and decentralized basis (DBB Katılımc1 Sözleşmesi, 2019). The Natural Food Network coordinates visits to producers' fields. Although it does not require organic certification, the Natural Food Network requires producers to

\footnotetext{
13 The research protocol under the institutional review board states that the author would not disclose the identity of the research subjects, so personal communication cited in this article is anonymous.

14 The total number of consumers in the Natural Food Network is 2,100 (since February 2016). They are distributed across 47 out of 80 cities of Turkey (personal communication, May 19, 2020).

15 Membership was lower than average in 2009, in its initial year. As discussed below, membership is higher in 2020.
} 
follow agro-ecological principles. These include, but are not limited to, bans on chemical use, artificial insemination, conventional ready-to-use milk supplements for livestock, and added sugar for honeybees. The AFN also encourages the use of local or heirloom seeds, the conservation of local varieties, and the sustainable management of natural resources (DBB Katılımcı Sözleşmesi, 2019). The Natural Food Network requires regular updates from its producers on their production techniques and feedback from consumers about its producers and products. The Natural Food Network does not set prices for products but encourages solidarity in terms of setting prices (Uysal \& Bektaş 2016). The assumption is that a fair price will address food security for consumers and livelihoods of producers (personal communication, May 19, 2020).

The Natural Food Network is run by voluntary moderators. As of 2020, there are five moderators, two of whom reside in Ankara. Prior to its recent annual meeting, all moderators were from Ankara. However, with the expansion of consumers to all of Turkey, the emphasis on Ankara has been removed (personal communication, May 18, 2020). The moderators facilitate feedback mechanisms among producers and consumers, and coordinate events and field days.

Since its establishment, the Natural Food Network has collaborated with the Buğday Association on different projects, including a project to provide direct, trustworthy access to natural and local produce project (Gida Topluluklar1, 2020). It cooperates with other food initiatives in Ankara on organizing workshops, special deliveries, and distribution days. It also supports the cooperatives in its network and encourages them to work together. These collaborations are based, in part, on the Natural Food Network's mission to encourage collectiveaction solutions to food system problems.

The Natural Food Network's response to COVID-19 In the early days of the pandemic, the ability of the
Natural Food Network to continue food distribution without major disruption received attention from Ankara Metropolitan Municipality. Natural Food Network moderators had several online meetings with the municipality and started a new initiative (in cooperation with the Buğday Association) to expand PGS to small producers around Ankara and provide market access for them (personal communication, May 19, 2020). Since the COVID-19 curfews were imposed, some of the Natural Food Network moderators, founders, or active producers have met several times with other AFNs to discuss the impact of COVID-19 and alternative pathways to build a resilient food system (personal communication, May 18, 2020). The Natural Food Network has pursued CSAs as a solidarity mechanism since its establishment and, during the COVID-19 crisis, moderators also called for a solidarity system between producers and consumers and among consumers to address the food security of urban consumers. Consumers paid extra for their purchases, and that revenue was then used to cover the cost of providing food for people in need. The calls were sporadic, and either the producer or network moderators could ask for a solidarity food package to be prepared anytime. ${ }^{16}$

The COVID-19 pandemic has increased the number of new members in the Natural Food Network system: March and April 2020 represented two of the busiest months in its previous four years. Several Natural Food Network producers have experienced an increase in sales, sometimes three times their regular sales, with a focus on nonperishable food items, such as flour and cracked wheat (bulgur). Some producers shared emails about the rise in demand and the pressure on them for shipment, whereas other producers and consumers also expressed concerns about the curfew measures and their impacts on courier shipments and producers' delivery systems. One producer reported running out of packing supplies and stopping shipments as a result. While most of the producers were able to continue the shipments and

\footnotetext{
16 As of May 25, 2020, 1092 Turkish lira (US\$160) was collected in the solidarity system, and packages were sent to nine families, along with additional gifts of soaps and healing creams. In the system, the consumer can choose items or pay $90 \%$ of selected items (prepared in advance by the producer). The producer then pays the remaining $10 \%$ and ships the items to a family or individual in need, defined by the consumer or the Natural Food Network moderators.
} 
address the rising demand, only one producer reported that he could not continue production and shipments due to COVID-19's impacts on his family (personal communication, May 18, 2020).

A few of the producers shared hopeful comments about the impact of COVID-19 on food systems and transformation potential for local and small production systems. Indeed, the Natural Food Network was approached by a rural development agency that asked it to provide training on how to shorten food supply chains. One moderator added that experts and policymakers "pay attention to [their] messages more carefully" and "work with [them] more closely" (personal communication, May 19,2020). One producer cooperative member who used to be a moderator reported an increasing number of people from Ankara going to their ancestors' villages to garden. He supported this growing interest, adding, "Although any interest in agriculture, particularly by the youth, should be celebrated, this is not [what we seek to accomplish] for agriculture" (personal communication, May 19, 2020). He emphasized his support for a group of local producers engaged in continuous cultivation of lands rather than retirees as part-time hobby gardeners. Because many of the producers in the Natural Food Network are small producers who rely on household labor, they did not report any challenges on labor shortages. Moderators were not directly involved in checking for sanitation and other practices employed by the producers since this is a decentralized initiative. Moderators shared additional education materials and their perspectives on COVID-19 impacts on the food system, and organized online Zoom meetings on food safety. Overall, the producers and consumers within the Natural Food Network did not report major bottlenecks in terms of access to and distribution of food. The diversity of products in their network, the availability of same products sold by different producers, and the transparency and open communication within the network has allowed its production and distribution systems to continue.

\section{Kadıköy Cooperative}

Organizational background

Kadıköy Cooperative started out as an initiative during the public forums organized in the Caferağa neighborhood of Kadıköy following the Gezi protests in 2013. After several gatherings in 2014 and a brief pause, the constituents convened again in 2015 to strengthen solidarity economies, support local production and consumption, popularize ecological and traditional farming methods, and transform consumption habits. Working closely with other consumer cooperatives in Istanbul and the Confederation of Farmer Unions (Çiftçi-SEN), volunteers compiled a list of producers to organize distribution of food packages in the neighborhood to those in need. After five distributions, the cooperative was officially established in 2016 and a small store opened. Until November 2019, the store was open with limited hours. Since then, a move to a bigger shop enabled the storage of a larger volume of items and longer hours (12-9 p.m. on weekdays, 10-6 p.m. on the weekend), making a larger number and variety of ecologically produced items available for urban consumers.

A nonprofit enterprise, the cooperative works on a volunteer, nonhierarchical, and participatory basis. It currently works with about 40 active volunteers. Five basic principles inform the activities of the cooperative: (1) "working with small producers without intermediaries" enables support for small-scale production; (2) "taking joint initiatives on production and consumption" helps devise collective processes by which to decide what, when, how, and how much to produce, which represents one definition of food sovereignty; (3) "collective work and sharing" create participatory and transparent mechanisms for internal and external organizing; (4) "ecological-social relations" are prioritized to support an ecological framework that cares about labor, nature, and the collective good; and (5) "social solidarity" is exercised to show solidarity with disadvantaged groups (Kadıköy Kooperatifi, n.d.). Any revenue supports the operations and sustainability of the cooperative, with a smaller amount delivered to other nonprofits for solidarity.

Kadıköy Cooperative sells food produced nonindustrially from heritage seeds and without chemicals or labor exploitation. There is a preference for producers in the following order: Women producers, organized producers, producers supporting 
organized consumer groups, disadvantaged producers, and subsistence farmers. A volunteer is assigned to every producer to maintain communications, place orders, and convey consumer feedback. The mediating work of the cooperative volunteers, who are also consumers, allows for a direct link between consumers and producers whereby producers' needs, worries, and problems can be communicated to consumers and solutions collaboratively found. Thus, the cooperative presents not only a shorter supply chain, but also a collective process to organize production and consumption. The store also serves as a meeting place for consumers and producers.

The store is open to the general public, and anyone who agrees with the above five principles is invited to join. The cooperative continues to procure from 42 producers and producer cooperatives in Turkey and supplies a range of products ${ }^{17}$ that include olives, olive oil, legumes, cheese, and fresh fruits and vegetables (when available). Eggs are supplied from one farm in Adapazar1 $160 \mathrm{~km}$ or 99 miles); walnuts and chestnuts come from a producer in Bolu (260 km or 162 miles). The distance expands as some olive oil is procured from a cooperative in the Aegean coast (748 km or 465 miles), and some legumes come from Turkey's Eastern region (1,228 km or 763 miles). Similar to the challenges facing the Natural Food Network, it is not possible to procure the diversity of products for the cooperative in and around Istanbul. The stories of where products come from and how and by whom they are produced are shared through product labels. As part of solidarity efforts, customers who shop at the store can also buy products to be picked up by someone else. The clientele mostly consists of those who live in the neighborhood. To support localization, the cooperative encourages people coming from other neighborhoods to shop to connect with AFNs in their own neighborhoods.

Prices are higher than those in conventional markets, yet often cheaper than the prices of organic-certified counterparts. Like the Natural Food Network, where there are no set prices, the cooperative refuses to negotiate with producers for cheaper prices to support their work. While these relatively higher prices limit who can shop at the store, the solidarity practice of buying for someone else so far has helped several people in need. Organizing laterally with other consumer cooperatives and food communities in Istanbul and receiving bulk shipments from producers is a big step toward reducing food prices. ${ }^{18}$ Kadiköy Cooperative actively engages in similar organizing efforts with other groups, with the understanding that different levels of organizing — starting from the neighborhood to other scales-is a must for food sovereignty and food justice. This approach places the cooperative as a political project that seeks to create mechanisms to counter structural challenges and to address the needs of consumers and producers together, instead of privileging one over the other, as it has been suggested of some AFNs (Alkon \& Guthman, 2017).

\section{Kadlköy Cooperative's response to COVID-19}

In response to an increasing number of COVID-19 cases in Turkey, cooperative volunteers performed a thorough cleaning of the store. Kadiköy Cooperative decided to keep the store open only two hours per day, while increasing the number of volunteers on duty from one to two. Because indoor shopping was deemed risky but the weather was still cold, the Cooperative devised a new system. The door was kept closed; no customer could go inside. A list of items available was put in the front window, and some of these were put on a table for display. A flap door allowed the transfer of items to the customer (outside) by the volunteer (inside). Cooperative shifts depend on volunteer presence, and only a handful of volunteers were able to be on duty at the store, as many live with a high-risk senior person, are themselves at risk, or need to commute by using public transportation. Yet, the cooperative was able to stay open most of the days.

\footnotetext{
17 In addition to food, Kadıköy Cooperative sells ecologically produced soap. Other non-food items produced by nonprofits and disadvantaged groups are also featured and sold to consumers as part of solidarity efforts.

18 For instance, 14 food and consumer groups ordered one and a half tons of lentils from two producers in Kars in 2019, leading to a reduction in transportation costs.
} 
The decision to keep the store open was informed by the needs of both producers and consumers. Cooperative sales generate significant income for many of the producers. Volunteers phoned the producers to check their well-being. The majority continued their production, processing, and shipments. While small producers relied on household labor, organized producers such as producer cooperatives continued to share the work. One producer, a farmer and baker using heritage seeds, stopped baking activities, but later resumed. Some producers over the age of 65 needed to obtain special permits, ${ }^{19}$ but, overall, the products sold in the store were easily and quickly replenished. Regarding consumers, it is not possible to tell whether interest increased or how many people came to shop from outside of the neighborhood. While sales did not equal those before the pandemic, two-hour operations often yielded more than half of the sales usually completed in a ninehour shift.

In short, the cooperative functioned with little disruption by keeping both the volunteers and the consumers safe so long as the producers were able to function. In addition to the already existing solidarity mechanism by which consumers may buy goods for prospective shoppers, the cooperative used its solidarity funds to prepare solidarity packages. Through word of mouth, 36 solidarity packages were distributed to migrants, neighbors who lost their jobs, and others in need, thereby strengthening solidarity in the neighborhood.

\section{Discussion}

Both organizations in Turkey have been working to "resocialize" the food system (Jarosz, 2008), with the consumer acquiring a more active role: consumers are asked to work closely with producers and activists (e.g., provide feedback, participate in cooperative activities) and engage with questions of food security, labor justice, and environmental sus- tainability. This involvement has become particularly important during COVID-19 as the response to a changing regulatory environment and restrictions have required flexible adaptations. While consumers in these AFNs continued to support small producers, they received regular updates about their challenges and possible disruption in distribution. They have also become more attuned to the food security of other consumers.

Both AFNs emphasize a decentralized and nonhierarchical structure. The voluntary moderators in the Natural Food Cooperative or volunteers in Kadıköy Cooperative who keep close communication with the producers ensure that the producers' livelihoods are protected and their questions and concerns are addressed. In the aftermath of COVID-19, both organizations regularly updated their consumers online and encouraged open communication about possible challenges. These quick, regular updates were critical to keeping the shop open and informing consumers daily (for Kadıköy Cooperative) and alert consumers about potential issues producers faced (for the Natural Food Cooperative). Not only did this close communication enhance the trust that had been built over time before COVID-19, it also allowed producers and consumers to work quickly and closely during times of crisis, such as COVID-19, in the form of preparation and distribution of solidarity packages for those in need. The solidarity packages constitute a new response, but build on and expand the cooperative economy models these AFNs follow.

Small producers within these AFNs in Turkey were able to continue their production and distribution without major issues during COVID-19. They provided their own labor or shared the labor with others (in the case of cooperatives) and did not need to travel far to process their items, which meant that even during the curfew measures they were able to supply fresh, clean, and healthy food to urban consumers. Both Istanbul and Ankara are

\footnotetext{
19 There was no cost associated with the special permits to continue cultivation in the fields. Due to restrictions on intercity travel, a producer could go to their fields (in the administrative area of another city) by providing proof of Farmer Registration, land rental documents, and a permit paper issued by the local security forces. For those producers over the age of 65 , the permit was dependent on the local security forces. In some places, producers were allowed to go to their own fields by showing Farmer Registration papers. In other places, they needed an additional permit issued by the Governor (which takes about 3 to 5 days for processing) to visit their own fields.
} 
densely populated urban centers that rely heavily on food shipments to the city. During the COVID19 crisis, Turkey has not yet reported any major challenges in food distribution nor food shortages. Whereas food loss and food waste have been concerns related to COVID-19 disruptions in the global food supply chain, the shorter food chains in the two AFNs discussed here have provided an outlet for small producers to connect with consumers and address the rising demand by urban consumers who had to cook more food at home.

\section{Conclusion}

Taken together, the response and initiatives of the two AFNs show that they were able to adapt to the disturbance in novel ways in a short time. Within the new regulatory landscape, they continued to provide economic opportunity for producers and healthy, fresh food for urban consumers. The trust that had been built between the consumers and producers through mutual practices over time proved vital at a time when the health crisis of COVID-19 demanded prompt and consistent responses and the cost of trusting others was particularly high. Both the Natural Food Network and Kadıköy Cooperative have been able to provide assurances to urban consumers and continue their operation. Their producers' responses, in turn, reflected their capacity and willingness to adapt in the face of uncertainty.

As a weakness, both of these AFNs relied on conventional shipment networks for the transport of food from producers to consumers. Pandemic regulations in Turkey did not have a high impact on the shipment of goods. Shipment companies continued their business without major interruptions, although they ran into delays at times. That Natural Food Network and Kadıköy Cooperative rely on these companies for the procurement of products raises questions about the sustained resilience of their operations: would they have worked the way they did, if shipment companies were to malfunction during the crisis?

As the pandemic continues, the AFNs in Turkey have already started conversations with other state and non-state actors (municipalities, consumer cooperatives, nonprofit organizations) on how to adapt and to make their networks more responsive to disturbances. Whereas there is some discussion on adaptation, we suggest that AFNs in Turkey also engage in further conversation about diversifying their distribution channels and discuss how to make them more adaptable in case of further lockdowns and other safety measures during the ongoing pandemic.

\section{Acknowledgments}

The authors would like to thank the volunteers of Kadıköy Cooperative and moderators and producers at Natural Food, Conscious Nutrition Network who participated in interviews. We also thank James C. Helicke, who provided editing suggestions. Finally, we thank three anonymous reviewers for their helpful feedback and valuable suggestions.

\section{References}

Abiral, B., \& Atalan-Helicke, N. (2020). Trusting food supply chains during the pandemic: Reflections from Turkey and the U.S. Food and Foodways, 28(3), 226236. https://doi.org/10.1080/07409710.2020.1790147

Ackerman-Leist, P. (2013). Rebuilding the foodshed: How to create local, sustainable, and secure food systems. Santa Rosa, CA: Post Carbon Institute.

Alkon, A., \& Guthman, J. (Eds.). (2017). The new food activism: Opposition, cooperation, and collective action. Oakland: University of California Press.

Allen, P. (2008). Mining for justice in the food system: Perceptions, practices, and possibilities. Agriculture and Human Values, 25, 157-161. https://doi.org/10.1007/s10460-008-9120-6

Aslan, B., \& Demir, Y. (2018). Organik Tarımla Beslenme: Türkiye ve Istanbul [Organic agriculture and diets: Turkey and Istanbul]. Beyond.Istanbul, 3, 56-60.

Atalan-Helicke, N. (2015). The halal paradox: Negotiating identity, religious values, and genetically engineered food in Turkey. Agriculture and Human Values, 32(4), 663-674. https://doi.org/10.1007/s10460-015-9585-z 
Atalan-Helicke, N. (2020). Access to healthy and clean food in Turkey: Food activism and mothers' concerns about shopping for change. In R. J. Bromwich, N. Richard, O. Ungar, M. Younger, \& M. Symons (Eds.), Environmental activism and the maternal: Mothers and mother earth in activism and discourse (pp. 99-132). Bradford, Ontario: Demeter.

Atasoy, Y. (2017). Commodification of global agrifood systems and agro-ecology: Convergence, Divergence and beyond in Turkey. Abington, UK, \& New York: Routledge.

Aydın, Z. (2010). Neo-liberal transformation of Turkish agriculture. Journal of Agrarian Change, 10(2), $149-187$. https://doi.org/10.1111/j.1471-0366.2009.00241.x

Béné, C. (2020). Resilience of local food systems and links to food security-A review of some important concepts in the context of COVID-19 and other shocks. Food Security, 12, 805-822. https://doi.org/10.1007/s12571-020-01076-1

Besky, S. 2014. The Darjeeling distinction: Labor and justice on fair-trade tea plantations in India. Berkeley: University of California Press.

Blake, M. K., Mellor, J., \& Crane, L. (2010). Buying local food: Shopping practices, place, and consumption networks in defining food as "local." Annals of the Association of American Geographers, 100(2), 409-426. https://doi.org/10.1080/00045601003595545

Buğday. (n.d.). Buğday hareketinin dünü ve bugünü (Buğday movement, past and present). Retrieved September 15, 2020, from https://www.bugday.org/blog/bugday-ekolojik-yasami-destekleme-dernegi/bugday-hareketinin-dunu-ve-bugunu/

Chase, L., \& Grubinger, V. (2014). Food, farms, and community: Exploring food systems. Lebanon: University of New Hampshire Press.

Chin, C. F. (2020). The impact of food supply chain disruptions amidst COVID-19 in Malaysia. Journal of Agriculture, Food Systems, and Community Development, 9(4), 161-163. https://doi.org/10.5304/jafscd.2020.094.031

Clapp, J. (2020, May 8). Spoiled milk, rotten vegetables and a very broken food system [Opinion column]. The New York Times. Retrieved from https://www.nytimes.com/2020/05/08/opinion/coronavirus-global-food-supply.html

CNNTürk.com. (2020, April 1). İçişleri Bakanlığı genelge ile duyurdu: işte yeni önlemler [The Ministry of Interior announced new measures]. Retrieved from https://www.cnnturk.com/video/turkiye/icisleri-bakanligi-genelge-ile-duyurdu-iste-yeni-onlemler

Crush, J., \& Si, Z. (2020). COVID-19 containment and food security in the Global South . Journal of Agriculture, Food Systems, and Community Development, 9(4), 149-151. https://doi.org/10.5304/jafscd.2020.094.026

Çanga, A. Ç., Kutlu, T., \& Çalışkan, H. (2018). Tarım Turizminin Dünyada ve Türkiye'deki uygulamaları. International Journal of Tourism, Economics and Business Sciences, 2(2), http://www.ijtebs.org/

Çelik, Z. (2016). Gıda Toplulukları ve Aracısız Ürün Ağı Analizi. Meyve Bilimi, 1, 26-32. Retrieved from https://dergipark.org.tr/en/pub/meyve

DBB Katılımcı Sözleşmesi. (2019). Natural Food Conscious Nutrition Network participant contract, v 2.1. Retrieved from https://drive.google.com/file/d/1HgDvMcI7AeTrgPWp9h7h1vbPfuaNT8RP/view

Değirmenci, S. (2020, May 2). Tarm ve gidada bu neyin hrzı? [Why this speed in agriculture and food?] Bianet. Retrieved from http://bianet.org/biamag/toplum/223681-tarim-ve-gidada-bu-neyin-hizi

Dewalt, K. M., \& DeWalt, B. R. (2011). Participant observation: A guide for fieldworkers (2nd ed.). Lanham, MD: AltaMira.

Doğançayır, C. M., \& Kocagöz, U. (2018). Alternatif Gı1da İnisiyatifleri Söyleşileri [Interviews with Alternative Food Initiatives]. Beyond.Istanbul, 3, 72-73.

Elejalde-Ruiz, A. (2020, May 6). Meat shortage means Chicago shoppers face buying limits, higher prices, fewer choices as coronavirus stresses supply. Chicago Tribune. Retrieved from https://www.chicagotribune.com/coronavirus/ctcoronavirus-meat-buying-limits-higher-prices-20200505-z3xknel2bbgihlebfa7gxdqwaq-story.html

Fraser, A. (2017). Global foodscapes: Oppression and resistance in the life of food. Abington, UK \& New York: Routledge.

Gallagher, D., \& Kirkland, P. (2020, April 27). Meat processing plants across the US are closing due to the pandemic. Will consumers feel the impact? CNN Business. Retrieved from https://www.cnn.com/2020/04/26/business/meat-processing-plants-coronavirus/index.html

Gida Toplulukları (2020). Food groups. Retrieved from http://gidatopluluklari.org/ 
Goodman, D., \& Goodman, M. K. (2009). Alternative food networks. In R. Kitchin \& N. Thrift (Eds.), International Encyclopedia of Human Geography (1 ${ }^{\text {st }}$ ed.) (pp. 208-220). Amsterdam: Elsevier.

Guthman, J. (2004). Agrarian dreams: The paradox of organic farming in California. Berkeley: University of California Press.

Guthman, J., Morris, A. W., \& Allen, P. (2006). Squaring farm security and food security in two types of alternative food institutions. Rural Sociology, 71(4), 662-684. https://doi.org/10.1526/003601106781262034

Harrison, H., Birks, M., Franklin, R., \& Mills, J. (2017). Case study research: Foundations and methodological orientations. In Forum: Qualitative Sozialforschung/Forum: Qualitative Social Research, 18(1), Art. 19. https://doi.org/10.17169/fqs-18.1.2655

Held, L. (2020, April 15). Food Distribution 1010: What happens when food supply is disrupted by a pandemic. Civil Eats. Retrieved from https://civileats.com/2020/04/15/food-distribution-101-what-happens-when-the-foodsupply-is-disrupted-by-a-pandemic/

Heper, M., \& Evin, A. (Eds.). (2011). State, democracy, and the military: Turkey in the 1980s. Berlin: Walter de Gruyter.

Holt Giménez, E., \& Shattuck, A. (2011). Food crises, food regimes and food movements: Rumblings of reform or tides of transformation? The Journal of Peasant Studies, 38(1), 109-144. https://doi.org/10.1080/03066150.2010.538578

Jarosz, L. (2008). The city in the country: Growing alternative food networks in Metropolitan areas. Journal of Rural Studies, 24(3), 231-244. https://doi.org/10.1016/j.jrurstud.2007.10.002

Kadıköy Kooperatifi. (n.d.). Hakkımızda. Retrieved June 15, 2020, from https://www.kadikoykoop.org/hakkimizda/

Kan, M., Tosun, F., Kan, A., Gokhan Dogan, H., Ucum, I., \& Solmaz, C. (2019). Young farmers in agriculture sector of Turkey: Young Farmers Support Program. Journal of Agricultural Science \& Technology, 21(1), 15-26. http://jast.modares.ac.ir/article-23-16634-en.html

Karadağ, K. (2020, March 24). Marketlere ve toplu taşıma araçlarına yönelik koronavirüs tedbirleri artırıldı [Coronavirus measures for markets and public transport increased]. Anadolu Ajansı. Retrieved from https://www.aa.com.tr/tr/koronavirus/marketlere-ve-toplu-tasima-araclarina-yonelik-koronavirus-tedbirleriartirildi/1776781

Larder, N., Lyons, K., \& Woolcock, G. (2014). Enacting food sovereignty: Values and meanings in the act of domestic food production in urban Australia. Local Environment, 19(1), 56-76. https://doi.org/10.1080/13549839.2012.716409

Levkoe, C. Z. (2014). The food movement in Canada: A social movement network perspective. Journal of Peasant Studies, 41(3), 385-403. https://doi.org/10.1080/03066150.2014.910766

Loconto, A., \& Hatanaka, M. (2018). Participatory guarantee systems: Alternative ways of defining, measuring, and assessing 'sustainability.' Sociologia Ruralis, 58(2), 412-432. https://doi.org/10.1111/soru.12187

Mecellem, J. G. (2018). Human rights trials in an era of democratic stagnation: The case of Turkey. Law \& Social Inquiry, 43(1), 119-151. https://doi.org/10.1111/1si.12260

Nelson, C. H., \& Stroink, M. L. (2014). Accessibility and viability: A complex adaptive systems approach to a wicked problem for the local food movement. Journal of Agriculture, Food Systems, and Community Development, 4(4), $191-206$. https://doi.org/10.5304/jafscd.2014.044.016

Nizam, D. \& Yenal, Z. (2020). Seed politics in Turkey: The awakening of a landrace wheat and its prospects. The Journal of Peasant Studies 47(4), 741-766. https://doi.org/10.1080/03066150.2019.1708725

Orhangazi, Ö., \& Yeldan, E. (2020). Re-making of the Turkish crisis (Working Paper Series 504). University of Massachusetts Amherst Political Economy Research Institute. Retrieved from https://www.peri.umass.edu/publication/item/1254-re-making-of-the-turkish-crisis

Özdemir, Ö. (2020, April 6). Koronavirüs salgını, Türkiye'de gıda ve tarm sektörü için risk barndiryor mu? Does coronavirus pandemic pose any risk for Turkey's food and agriculture sector?] BBC News Turkey. Retrieved from https://www.bbc.com/turkce/haberler-turkiye-52175470

Öztürk, M., Topaloğlu, B., Hilton, A., \& Jongerden, J. (2018). Rural-urban mobilities in Turkey: Socio-spatial perspectives on migration and return movements. Journal of Balkan and Near Eastern Studies, 20(5), 513-530. https://doi.org/10.1080/19448953.2018.1406696

Perrett, A., \& Jackson, C. (2015). Local food, food democracy, and food hubs. Journal of Agriculture, Food Systems, and Community Development, 6(1), 7-18. https://doi.org/10.5304/jafscd.2015.061.003 
Pratley, E. M., \& Dodson, B. (2014). The spaces for farmers in the city: A case study comparison of Direct Selling Alternative Food Networks in Toronto, Canada and Belo Horizonte, Brazil. Canadian Food Studies / La Revue Canadienne Des études Sur L'alimentation, 1(1), 72-87. https://doi.org/10.15353/cfs-rcea.v1i1.22

Republic of Turkey Ministry of Development. (2019). On birinci kalkinma plant [Eleventh development plan] (2019-2023). Republic of Turkey Ministry of Development. Retrieved from http://www.sbb.gov.tr/wp-content/uploads/2019/07/OnbirinciKalkinmaPlani.pdf

Skerritt, J., Patton, L., Onu, E. (2020, April 9). It's getting a lot harder to ship food around the world. Bloomberg. Retrieved from https://www.bloomberg.com/news/articles/2020-04-09/it-s-getting-a-lot-harder-to-ship-food-around-the-world

Soysal Al, I., \& Küçük, B. (2019). In-between anxiety and hope: Trusting an alternative among 'alternatives' in the (post) organic food market in Turkey. The International Journal of Sociology of Agriculture and Food, 25(2), 173-190. https://doi.org/10.48416/ijsaf.v25i2.42

Sumner, J., Mair, H., \& Nelson, E. (2010). Putting the culture back into agriculture: Civic engagement, community and the celebration of local food. International Journal of Agricultural Sustainability, 8(1-2), 54-61. https://doi.org/10.3763/ijas.2009.0454

Sumner, J., McMurtry, J. J., \& Renglich, H. (2014). Leveraging the local: Cooperative food systems and the Local organic food co-ops network in Ontario, Canada. Journal of Agriculture, Food Systems, and Community Development, 4(3), 47-60 https://doi.org/10.5304/jafscd.2014.043.004

Temürcü, C. (2020, April 16). Nasil besleneceğiz? Krizler çağında gıda güvencesi [How are we going to be fed? Food security in an age of crisis] [Blog post]. Retrieved from http://ahmetsaltik.net/tag/ceyhan-temurcu/

Urgenci. (2016). Mapping local and solidarity-based partnerships between producers and consumers in the Mediterranean Basin (International Network URGENCI report). Retrieved from http://urgenci.net/wp-content/uploads/2016/03/UR Med-MAPPING RESULTS-0416.pdf

Uysal, Ö. K., \& Bektaş, Z. K. (2016). Organik. tarmda katulmon garanti sistemlerinin Türkiye'de uygulanabilirliüi [Applicability of participatory guarantee systems in organic agriculture in Turkey]. 12 Ulusal Tarım Ekonomisi Kongresi [Proceedings of 12th National Agricultural Economy Congress], 243-252.

Torero Cullen, M (2020, March 29). COVID-19 and the risk to food supply chains: How to respond? Food and Agriculture Organization of the United Nations (FAO). Retrieved from http://www.fao.org/3/ca8388en/CA8388EN.pdf

World Bank. (2017). Country partnership framework. for the Republic of Turkey for the period FY18-FY21 (Report No. 11096-TR). Retrieved from http://documents.worldbank.org/curated/en/585411504231252220/pdf/Turkey-CPF-08072017.pdf

World Bank. (2020). The World Bank in Turkey. Retrieved from https://www.worldbank.org/en/country/turkey/overview\#3 (Updated October 19, 2020)

Worstell, J., \& Green, J. (2017). Eight qualities of resilient food systems: Toward a Sustainability/Resilience Index. Journal of Agriculture, Food Systems, and Community Development, 7(3), 23-41. https://doi.org/10.5304/jafscd.2017.073.001

Yıldırım, A. E. (2020, May 5) Sarımsak, soğan, patates enflasyonu [Inflation in the prices of garlic, onions and potatoes]. Tarim Dünyasi. Retrieved from https://www.tarimdunyasi.net/2020/05/05/sarimsaksoganpatates-enflasyonu/

Zırh, B. C., Karakılıç, İ. Z., Çetinkaya, Ö., Ayaeş, S., Özsoy, A., \& Karabıyık, E. (2020) Virus mü, yoksulluk mu? Korona viriis salgnnmn mevsimlik gezici tarm işcileri ve onlarn çocuklarn ile bitkisel üretime olast etkisi [Virus or poverty? The impact of coronavirus pandemic on seasonal agricultural labor, their children and agricultural production]. Ankara: Kalkınma Atölyesi \& Uluslararası Çalısma Örgütü (ILO). Retrieved from http://www.ka.org.tr/dosyalar/file/Yayinlar/Raporlar/TURKCE/Virus\%20mu\%20yoksulluk\%20mu.pdf

Zurayk, R. (2020). Pandemic and food security: A view from the Global South. Journal of Agriculture, Food Systems, and Community Development, 9(3), 17-21. https://doi.org/10.5304/jafscd.2020.093.014 